Acta Cryst. (1991). C47, 1198-1202

\title{
Structure of $\left(71^{5}\right.$-C yclopentadienyl)(I ,2,3,4,4a, 10 a-716-2-methyl- dibenzo[h,e][l,4)dioxine)iron(II) Hexafluorophosphate at $163 \mathrm{~K}$
}

\author{
BY K. A. ABBOUD AND S. H. SIMONSEN \\ Department of Chemistry, U niversity of Texas at Austin, Austin, TX 78712, USA \\ AND A. PIORKO AND R. G. SUTHERLAND \\ Department of Chemistry, University of Saskatchewan, Saskatoon, Saskatchewan, Canada S7N OWO
}

(Received 7 August 1990; accepted 19 December 1990)

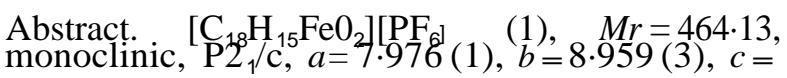
$24.936(8) A, B=99.00(2)^{\circ}, V=1760$ (1) $A^{3}, Z=4$, $D x=1.751 \mathrm{gem}^{-3}, \quad \mathrm{~A} .(\mathrm{M} \circ \mathrm{Ka})=0.71069 \mathrm{~A}, \quad \mathrm{~L}=$ $10.153 \mathrm{em}-1, \quad F(000)=936, \quad T=163(2) \mathrm{K}, \quad$ fullmatrix least-squares refinement of $(\mathrm{I})$ converged to $\mathrm{R}$ $=0.047$ and $w R=0.044$ with 3103 reflections $[/>$ $3 u(I)]$ of 4065 total unique reflections. The dihedral angle between the arene rings of the dioxine ligand is 173.8 (It; the $\mathrm{C}-\mathrm{O}$ bond distances to the coordinated ring are significantly shorter than those of the uncoordinated ring. Inclusion of electronegative
\end{abstract}

0108-2701191/061198-05\$03.00 atoms (i.e. $\mathrm{N}$ ) in the arene rings of thianthrenes and complexation of iron cyclopentadienyl ( $\mathrm{FeCp}$ ) to the arene rings, resulted in flattening of the dihedral angle. The effect was similar, but more pronounced, in phenoxathiins. The effect of an electron-releasing group (methyl) substituent on the arene ring of a thianthrene $\mathrm{FeCp}$ complex was to decrease the dihedral angle; but, inconsistently, two methyl groups (in the 2 and 7 positions) increased the angle. Dibenzodioxine and other dibenzodioxines with varying numbers of chloro substituents are planar. The dihedral angle of the title compound is $173.8^{\circ}$. It

(c) 1991 International Union of Crystallography 
is not clear whether this is owing to the influence of the substituent methyl group, complexation, or packing forces.

Introduction. Previous studies of the synthesis, structure and reactivity of tricyclic heterocycles (II) complexed with an $\mathrm{FeCp}$ moiety indicated that both the location of the $\mathrm{FeCp}$ moiety [inside or outside of the heterocycle fold (III)] and the presence of a substituent on the heterocycle may influence the dihedral angle between the arene rings. In the thianthrene complex (Abboud, Lynch, Simonsen, Pibrko \& Sutherland, 1990) the $\mathrm{FeCp}$ moiety was located inside the fold in one molecule of the asymmetric unit and outside the fold in the other; in the 2methylthianthrene complex (Simonsen, Lynch, Sutherland \& Pi6rko, 1985) it was located inside the fold. However, there were significant differences in the dihedral angles of the thianthrene skeletons. This difference may result from the action of packing forces in the crystal, or it may be owing to the presence of the methyl substituent in the 2methylthianthrene complex. To extend the investigation of the influence of the substituents and complexation with $\mathrm{FeCp}$ upon the geometry of the three-ring heterocyclic ligand, (I) was synthesized and its crystal structure determined.
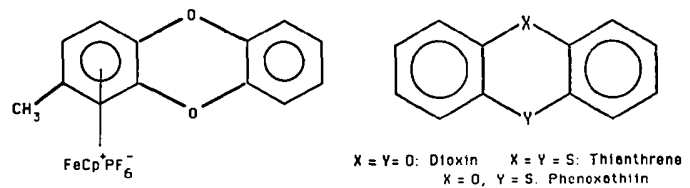

(I)

(II)
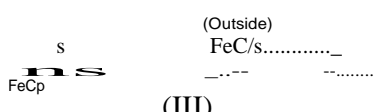

(III)

Experimental. The title compound was synthesized by the reaction of catechol with (7]-3,4-dichlorotoluene) $\left(77^{5}-\mathrm{Cp}\right)$ iron( II) hexafluorophosphate following the described procedure (Sutherland, Pi6rko, L ee, Simonsen \& Lynch, 1988). Crystals of the complex were grown from an acetone-diethyl ethermethylene chloride solution at ca $255 \mathrm{~K}$. A needleshaped orange-yellow crystal, $0.12 \times 0.23 \times$ $0.47 \mathrm{~mm}$, was mounted and transferred to a Syntex $\mathrm{n}_{1}$ diffractometer equipped with a graphite monochromator (Mo Ka radiation), where it was maintained in an environment of dry $\mathrm{N}_{2}$ at $163(2) \mathrm{K}$ with a Syntex LT-1 low-temperature delivery system. Preliminary investigations revealed the crystal system to be monoclinic. 45 strong reflections, $25 \cdot 33$ $2034.73^{\circ}$, were used to refine the unit-cell parameters. 8420 reflections (h, $0-10$; $k,-11-11$; l, - 32-32) were collected by thew-scan method, 4065 unique reflections, $\mathrm{Rint}=0.023 ; 20$ range $4--55^{\circ}$ ( $\max$. $\sin 0 / A=0.6497 A r^{1}$, I ow scan at $4--8^{\circ} \min -1$, depending upon intensity. Background measurements were taken at both ends of the scan with w displaced by $1.0^{\circ}$ from the $\mathrm{Ka} 1,2$ peak; each measurement was made for one-half of the scan time. Intensities of four reflections $(135,14 T, 148,126)$ were remeasured every 96 reflections to monitor instrument stability and crystal decay; max. correction was $1.6 \%$. Absorption corrections based on measured crystal faces (Riley \& Davis, 1976) were applied; min., max. transmission coefficients $0.695,0.874$. An extinction correction was not applied. The structure was solved by the heavy-atom (Patterson) method (SHELX76; Sheldrick, 1976) which revealed the position of the Fe atom; the remainder of the atoms were located from difference Fourier maps. Refinement was carried out by full-matrix least squares in SH ELX76 with anisotropic thermal parameters for the non- $\mathrm{H}$ atoms and isotropic thermal parameters for the $\mathrm{H}$ atoms. I $\mathrm{w}(|\mathrm{Fal}-| \mathrm{FC} \mid)^{2}$ was minimized, where $\mathrm{w}=$ II (ulF olf, $u(F$ a $)=0.5 \mathrm{ki}-{ }^{112}\left\{\left[\mathrm{u}(!) f+(0.02 /)^{2}\right\}^{112}\right.$, I $=(/$ peak $-\mathrm{lbkg})($ scan rate $)$ and $u(/)=(/ \text { peak }+\mathrm{lbkg})^{112}$ $x$ (scan rate). $k$ is the correction due to decay and $L p$ effects, and 0.02 is a factor used to downweight intense reflections and to account for instrument instability. Convergence was attained with Rand wR of 0.047 and 0.044 , respectively, for 3103 reflections of intensity larger than $3 u(/) ; 962$ reflections were considered to be unobserved. In the last cycyle of refinement, 313 variables were refined to a goodnessof-fit of 2.88; the largest shift/e.s.d. did not exceed 0.08 ; min. and max. peaks in the difference Fourier map were -0.44 and $1.43 e A-{ }^{3}$, respectively. The largest residual peak was $0.88 \mathrm{~A}$ from the $\mathrm{Fe}$ atom and thus was attributed to its anisotropy. The linear absorption coefficient was calculated with values from International Tables for X-ray Crystallography (1974, V ol. IV , p. 55). Scattering factors for non-H atoms were taken from Cromer \& M ann (1968) with anomalous-dispersion corrections from Cromer \& Liberman (1970); those of $\mathrm{H}$ atoms were from Stewart, Davidson \& Simpson (1965). The leastsquares-planes program was supplied by Cordes (1983); other programs used are cited in reference II of Gadol \& Davis (1982). Positional parameters of all non-H atoms with their equivalent isotropic thermal parameters are given in Table I. Bond lengths and angles for the non- $\mathrm{H}$ atoms are listed in Table 2. * Fig. I shows the thermal-ellipsoids drawing of (I) with the atom-numbering scheme.

\footnotetext{
* Lists of structure factors, anisotropic thermal parameters, crystallographic data, bond lengths and angles including $\mathrm{H}$ atoms and $\mathrm{H}$-atom parameters have been deposited with the British Library Document Supply Centre as Supplementary Publication No. SUP 53854 (31 pp.). Copies may be obtained through The Technical Editor, International Union of Crystallography, 5 A bbey Square, Chester $\mathrm{CHI} 2 \mathrm{HU}$, England.
} 
Table 1. Fractional coordinates and equivalent isotropic thermal parameters $\left(A^{2}\right)$ for the non- $H$ atoms of (I)

\begin{tabular}{|c|c|c|c|c|}
\hline & $x$ & $y$ & Z & U* \\
\hline $\mathrm{Fe}$ & $0.36640(6)$ & $0.18949(5)$ & $0.16340(2)$ & $0.02946(13)$ \\
\hline$p$ & 0.08859 (13) & $0.35356(I I)$ & $-0.14762(4)$ & 0.0453 (3) \\
\hline $\mathrm{FI}$ & $0.0857(4)$ & $0.2337(3)$ & $-0.10150(10)$ & 0.0789 (1I) \\
\hline $\mathrm{F} 2$ & $0.0913(3)$ & $0.4732(3)$ & $-0.19467(10)$ & $0.0743(10)$ \\
\hline F3 & $0.2893(3)$ & $0.3506(3)$ & $-0 \cdot 13868(12)$ & $0.0934(12)$ \\
\hline F4 & 0.0861 (4) & $0.2238(3)$ & $-0.19089(I I)$ & $0.0866(12)$ \\
\hline F5 & $-0 \cdot 1120(3)$ & 0.3521 (3) & $-0.15857(15)$ & 0.1035 (14) \\
\hline F6 & $0.0908(6)$ & $0.4823(3)$ & $-0.10641(12)$ & $0.127(2)$ \\
\hline os & 0.5741 (3) & $0.0205(2)$ & $0.08315(9)$ & $0.0405(8)$ \\
\hline 010 & $0.3468(3)$ & $0.2486(3)$ & $0.03666(9)$ & $0.0438(8)$ \\
\hline $\mathrm{Cl}$ & $0.1636(4)$ & $0.1886(4)$ & $0 \cdot 10051$ (13) & $0.0375(10)$ \\
\hline $\mathrm{C} 2$ & $0.1220(4)$ & $0 \cdot 1025(4)$ & 0.14398 (13) & $0.0366(11)$ \\
\hline C3 & 0.2361 (5) & $-0.0104(4)$ & $0.16573 \quad(14)$ & $0.0399(11)$ \\
\hline C4 & $0.3871(4)$ & $-0.0364(4)$ & 0.14506 (14) & $0.0372(11)$ \\
\hline $\mathrm{C} 4 \mathrm{a}$ & $0.4257(4)$ & $0.0472(3)$ & 0.10069 (13) & $0.0338(10)$ \\
\hline $\mathrm{CSa}$ & $0.6144(4)$ & $0.1169(4)$ & 0.04359 (13) & $0.0350(10)$ \\
\hline $\mathrm{C} 6$ & $0.7705(5)$ & $0.0983(4)$ & $0.02683(15)$ & 0.0449 (13) \\
\hline $\mathrm{C} 7$ & $0.8150(6)$ & 0.1907 (5) & $-0.0126(2)$ & $0.056(2)$ \\
\hline $\mathrm{C} 8$ & $0.7059(6)$ & $0.2993(5)$ & $-0.0356(2)$ & $0.060(2)$ \\
\hline $\mathrm{C} 9$ & 0.5501 (6) & $0.3164(5)$ & $-0.01920(15)$ & 0.0495 (13) \\
\hline $\mathrm{C9a}$ & $0.5058(4)$ & $0.2267(3)$ & 0.02068 (13) & $0.0363(11)$ \\
\hline $\mathrm{ClOa}$ & $0.3127(4)$ & $0.1599(3)$ & 0.07832 (13) & $0.0351(10)$ \\
\hline C1I & $0.4130(5)$ & $0.4124(4)$ & $0.1774(2)$ & $0.0416(12)$ \\
\hline $\mathrm{Cl} 2$ & $0.5670(5)$ & $0.3358(4)$ & $0.1781(2)$ & $0.0410(12)$ \\
\hline $\mathrm{Cl3}$ & $0.5777(5)$ & $0.2272(4)$ & $0.2194(2)$ & 0.0433 (13) \\
\hline $\mathrm{Cl} 4$ & $0.4307(5)$ & $0.2366(4)$ & 0.24391 (14) & $0.0423(12)$ \\
\hline CIS & 0.3291 (5) & $0.3512(4)$ & $0.2179(2)$ & $0.0423(12)$ \\
\hline $\mathrm{Cl} 6$ & $-0.0345(5)$ & $0.1365(5)$ & $0 \cdot 1680(2)$ & 0.0512 \\
\hline
\end{tabular}

*For anisotropic atoms, the $U$ value is $U$ eq, calculated as $U$ eq $=$ (li3)L;LjU;ja;*a/A;j.

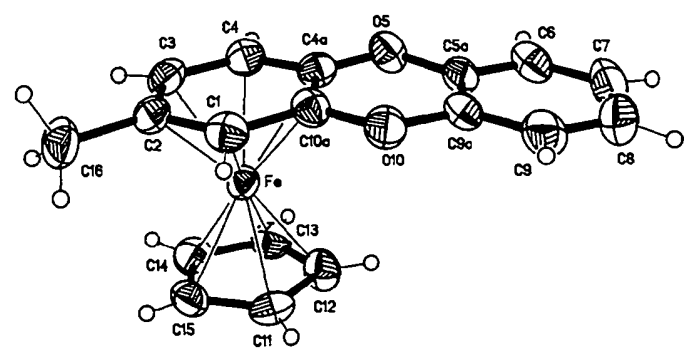

Fig. I. M olecular structure of (1), with $50 \%$ probability ellipsoids, showing the atom-numbering scheme.

Discussion. The crystal structure of (I) was studied in a continuing effort to investigate the variation of the dihedral angles of tricyclic heterocycles by (1) replacing some of the $C$ atoms in the terminal arene rings with more electronegative atoms (e.g. N), (2) placing substituents on the rings and (3) complexation of these heterocycles with FeCp. Comparison of the structures of a number of phenoxathiins, Table 3, reveals that the dihedral angle of the heterocycle flattens and approaches $180^{\circ}$ with the inclusion of $\mathrm{N}$ atoms in the ring. The effect of complexation parallels the influence of electron-withdrawing substituents in the rings. However, in some cases pack-. ing effects may be more important than electronic effects.
Table2. Bond lengths ( $A$ ) and angles $C$ ) for the non- $H$ atoms of $(\mathrm{I})$

\begin{tabular}{|c|c|c|c|c|}
\hline & 2 & 3 & $1-2$ & $1-2-3$ \\
\hline $\mathrm{Cl}$ & $\mathrm{Fe}$ & & $2.069(3)$ & \\
\hline $\mathrm{C} 2$ & $\mathrm{Fe}$ & & 2.085 (3) & \\
\hline C3 & $\mathrm{Fe}$ & & $2.075(3)$ & \\
\hline C4 & $\mathrm{Fe}$ & & $2.087(3)$ & \\
\hline C4a & $\mathrm{Fe}$ & & $2 \cdot 128(3)$ & \\
\hline $\mathrm{ClOa}$ & $\mathrm{Fe}$ & & $2 \cdot 114(3)$ & \\
\hline C11 & $\mathrm{Fe}$ & & 2.051 (4) & \\
\hline $\mathrm{Cl} 2$ & $\mathrm{Fe}$ & & $2.056(4)$ & \\
\hline C13 & $\mathrm{Fe}$ & & 2.041 (4) & \\
\hline $\mathrm{Cl} 4$ & $\mathrm{Fe}$ & & 2.037 (4) & \\
\hline $\mathrm{CIS}$ & $\mathrm{Fe}$ & & $2.039(4)$ & \\
\hline $\mathrm{FI}$ & $P$ & F2 & $1.576(3)$ & $179 \cdot 38(14)$ \\
\hline $\mathrm{FI}$ & P & F3 & & $90.9(2)$ \\
\hline F1 & $\mathrm{P}$ & F4 & & 89.83 (14) \\
\hline F1 & $P$ & F5 & & $89.5(2)$ \\
\hline F2 & P & F3 & $1.592(3)$ & $89 \cdot 2(2)$ \\
\hline F2 & $\mathrm{P}$ & F4 & & 89.56 (14) \\
\hline $\mathrm{F} 2$ & $\mathrm{P}$ & F5 & & $90.5(2)$ \\
\hline $\mathrm{F} 2$ & $\mathrm{P}$ & F6 & & $89 \cdot 28$ (15) \\
\hline F3 & $P$ & F4 & $1.581(3)$ & $89 \cdot 3(2)$ \\
\hline F3 & $\mathrm{P}$ & F5 & & $177-7(2)$ \\
\hline F3 & $\mathrm{P}$ & F6 & & $90 \cdot 7(2)$ \\
\hline F4 & $P$ & F5 & $1.584(3)$ & $88.4(2)$ \\
\hline F4 & $P$ & F6 & & $178.8(2)$ \\
\hline F5 & $P$ & F6 & $1.580(3)$ & 91.5 (2) \\
\hline F6 & $P$ & $\mathrm{FI}$ & 1.543 (3) & $91 \cdot 3(2)$ \\
\hline C4a & 05 & C5a & 1.346 (4) & $115 \cdot 7$ (2) \\
\hline C5a & 05 & & $1.386(4)$ & \\
\hline C9a & 010 & $\mathrm{C} ! \mathrm{Oa}$ & $1.401(4)$ & $115 \cdot 5(2)$ \\
\hline $\mathrm{ClOa}$ & 010 & & $1.369(4)$ & \\
\hline C2 & $\mathrm{Cl}$ & $\mathrm{C} ! \mathrm{Oa}$ & 1.412 (5) & $121 \cdot 0(3)$ \\
\hline $\begin{array}{l}\mathrm{ClOa} \\
\mathrm{C} 3\end{array}$ & $\begin{array}{l}\mathrm{Cl} \\
\mathrm{C} 2\end{array}$ & C16 & $\begin{array}{l}1.412(5) \\
1.411(5)\end{array}$ & $121 \cdot 4(3)$ \\
\hline C3 & $\mathrm{C} 2$ & $\mathrm{Cl}$ & & $118 \cdot 2(3)$ \\
\hline $\mathrm{Cl} 6$ & $C 2$ & $\mathrm{C} 1$ & $1.497(6)$ & $120 \cdot 4(3)$ \\
\hline C4 & C3 & $\mathrm{C} 2$ & $1 \cdot 401(5)$ & $121 \cdot 2(3)$ \\
\hline $\mathrm{C} 4 \mathrm{a}$ & C4 & C3 & $1 \cdot 410(5)$ & $120.4(3)$ \\
\hline $\mathrm{C} ! 0 \mathrm{a}$ & $\mathrm{C} 4 \mathrm{a}$ & 05 & $1.409(4)$ & $122.6(3)$ \\
\hline $\mathrm{C} ! \mathrm{Oa}$ & $\mathrm{C} 4 \mathrm{a}$ & $\mathrm{C} 4$ & & $119 \cdot 1$ (3) \\
\hline 05 & C4a & C4 & & $118 \cdot 2(3)$ \\
\hline C6 & C5a & C9a & $1.385(5)$ & 119.9 (3) \\
\hline C6 & C5a & 05 & & $117 \cdot 4$ (3) \\
\hline C9a & C5a & 05 & $1 \cdot 374(4)$ & $122 \cdot 7$ (3) \\
\hline $\mathrm{C} 7$ & C6 & C5a & $1.373(6)$ & $119 \cdot 3(4)$ \\
\hline C8 & $\mathrm{C7}$ & $\mathrm{C} 6$ & $1.370(6)$ & $120 \cdot 7(4)$ \\
\hline C9 & C8 & $\mathrm{C} 7$ & $1 \cdot 377(7)$ & $119 \cdot 8(4)$ \\
\hline C9a & C9 & $\mathrm{C} 8$ & $1.367(5)$ & 119.9 (4) \\
\hline 010 & $\mathrm{C} 9 \mathrm{a}$ & C5a & & $121 \cdot 4$ (3) \\
\hline 010 & $\mathrm{C} 9 \mathrm{a}$ & C9 & & 118.2 (3) \\
\hline C5a & C9a & C9 & & $120.4(4)$ \\
\hline 010 & $\mathrm{ClOa}$ & $\mathrm{Cl}$ & & $118 \cdot 1$ (3) \\
\hline 010 & $\mathrm{C} ! 0 \mathrm{a}$ & $\mathrm{C} 4 \mathrm{a}$ & & $121 \cdot 7$ (3) \\
\hline $\mathrm{Cl}$ & $\mathrm{ClOa}$ & C4a & & $120 \cdot 1$ (3) \\
\hline $\mathrm{Cl} 2$ & CII & CIS & $1.405(5)$ & $108 \cdot 3(3)$ \\
\hline CIS & Cll & & $1 \cdot 406(6)$ & \\
\hline $\mathrm{Cl} 3$ & $\mathrm{Cl} 2$ & $\mathrm{Cll}$ & $1.408(5)$ & $107 \cdot 4(3)$ \\
\hline C14 & $\mathrm{C} 13$ & $\mathrm{Cl} 2$ & $1.407(6)$ & 108.5 (3) \\
\hline C15 & C14 & $\mathrm{Cl} 3$ & $1.403(5)$ & 107.6 (3) \\
\hline $\mathrm{Cll}$ & C15 & $\mathrm{Ci} 4$ & & $108 \cdot 2(3)$ \\
\hline
\end{tabular}

Electron-withdrawing groups and complexation have a similar, but smaller, effect on the dihedral angles of thianthrenes [thianthrene $\left(127 \cdot 1^{\circ}\right)$ and 1azathianthrene $\left(130.4^{\circ}\right)$, Larson, Simonsen, Martin, Smith \& Puig-Torres (1984); (71)-cyclopentadienyl)(11 ${ }^{6}$-thianthrene)iron(II) hexafluorophosphate $\left(143 \cdot 10\right.$ and $\left.136 \cdot 3^{\circ}\right)$, A bboud et a!. (1990) and 1,4diazathianthrene $\left(138.9\right.$ and $\left.137.0^{\circ}\right)$, Larson, Simonsen, Lam, M artin, Lindsay \& Smith (1985)]. 
Table 3. Comparison of structures

\begin{tabular}{|c|c|c|}
\hline & $\begin{array}{l}\text { Dihedral } \\
\text { angle } \bigcap\end{array}$ & R eference \\
\hline Phenoxathiin & $147-7$ & Kimura \& Simonsen ( 1981). \\
\hline 3-A zaphenoxathiin & $168 \cdot 8$ & $\begin{array}{l}\text { Caldwell, M artin, Simonsen, } \\
\text { Inners \& W illcutt (1981). }\end{array}$ \\
\hline I,3-Diazaphenoxathiin & $165 \cdot 4$ & $\begin{array}{l}\text { Puig-Torres, M artin, Larson \& } \\
\text { Simonsen (1984). }\end{array}$ \\
\hline I ,4,9-Triazaphenoxathiin & $172 \cdot 5$ & $\begin{array}{l}\text { Larson, Simonsen, Martin \& } \\
\text { Smith (1985). }\end{array}$ \\
\hline 7-Chloro-1-azaphenoxathiin & $175 \cdot 3$ & $\begin{array}{l}\text { M artin, Korp, Turley \& } \\
\text { Bernal (1978). }\end{array}$ \\
\hline 8-Chloro-1-azaphenoxathiin & $176 \cdot 8$ & $\begin{array}{l}\text { M artin, Korp, Turley \& } \\
\text { Bernal ( 1978). }\end{array}$ \\
\hline $\begin{array}{l}\text { 1-N itrophenoxathiin } \\
\text { ( } 2 \text { molecules/asymmetric } \\
\text { unit) }\end{array}$ & $\begin{array}{l}163 \cdot 8 \\
145 \cdot 7\end{array}$ & $\begin{array}{l}\text { Hossain, Dwiggins, van der } \\
\text { Helm, Gupta, Turley } \& \\
\text { M artin ( 1982). }\end{array}$ \\
\hline 9-N itro-1-azaphenoxathiin & $178 \cdot 3$ & $\begin{array}{l}\text { Hossain, Dwiggins, van der } \\
\text { Helm, Gupta, Turley } \& \\
\text { Martin (1982). }\end{array}$ \\
\hline $\begin{array}{l}\text { 1-Dimethylamino- 2,3- } \\
\text { diazaphenoxathiin }\end{array}$ & $174 \cdot 0$ & $\begin{array}{l}\text { Womak, Turley, M artin, } \\
\text { Kimura \& Simonsen (1981). }\end{array}$ \\
\hline $\begin{array}{l}\text { 6,7,9-T rimethyl-4-aza- } \\
\text { phenoxathiin }\end{array}$ & $180 \cdot 0$ & $\begin{array}{l}\text { Lynch, Simonsen, M artin, } \\
\text { Puig-Torres \& Smith (1984). }\end{array}$ \\
\hline $\begin{array}{l}77^{5} \text {-Cyclopentadienyl)( } 77^{6} \text {-phen- } \\
\text { oxathiin)iron(II) Hexafluoro- } \\
\text { phosphate }\end{array}$ & $178 \cdot 6$ & $\begin{array}{l}\text { Simonsen, Lynch, Sutherland } \\
\text { \& Piorko (1984). }\end{array}$ \\
\hline
\end{tabular}

Electron-releasing groups, however, do not show a similarly consistent trend. Whereas the methyl group in 2-methylthianthrene $\mathrm{FeC} p$ complex (Simonsen et al., 1985), is believed to cause the ring to fold [dihedral angle, 127.4 (3t, compared to $143.1(2)^{\circ}$ in the thianthrene FeCp complex], the dihedral angle in 2,7-dimethylthianthrene [136.96 ${ }^{\circ}$, W eakley (1982)] is larger than that of thianthrene. Thus, the two methyl groups were accompanied by ring flattening.

Uncomplexed dibenzodioxine is a planar molecule (Singh \& M CK inney, 1978), and dioxines with two (B oer \& N orth, 1972), four (B oer, van Remoortere, North \& Neuman, 1972) or six (Cantrell, Webb \& M abis, 1969) chloro substituents were found to be planar or nearly so. In the title compound the dihedral angle is 173.8 (It, which clearly shows that the three-ring heterocycle deviates from planarity in spite of complexation to $\mathrm{FeCp}$. The folding in (I) may be attributed to the presence of the methyl group as an electron-rel easing substituent. How ever, it is not clear yet whether this effect is electronic in nature or due to packing forces.

The $\mathrm{Fe}$ atom is centered above the $\mathrm{Cp}$ ring; however, bonding between $\mathrm{Fe}$ and the arene ring is asymmetrical. The longest $\mathrm{Fe}-\mathrm{C}$ distances are to $C$ atoms adjacent to 0 atoms. This phenomenon is also observed in similar compounds reported by Simonsen et al. (1985) and Lynch, Thomas, Simonsen, Pi6rko \& Sutherland (1986). The Fe$\mathrm{C} 4 \mathrm{a}$ and Fe-C10a distances are 2.128 (3) and 2.114 (3) $A$, respectively, which represent the longest $\mathrm{Fe}-\mathrm{C}$ distances in (1), indicating that the $\mathrm{Fe}$ atoms are not exactly centered upon the arene rings. In addition, the $\mathrm{C}-\mathrm{C}$ distances of the coordinated ring are longer than the $\mathrm{C}-\mathrm{C}$ distances of the

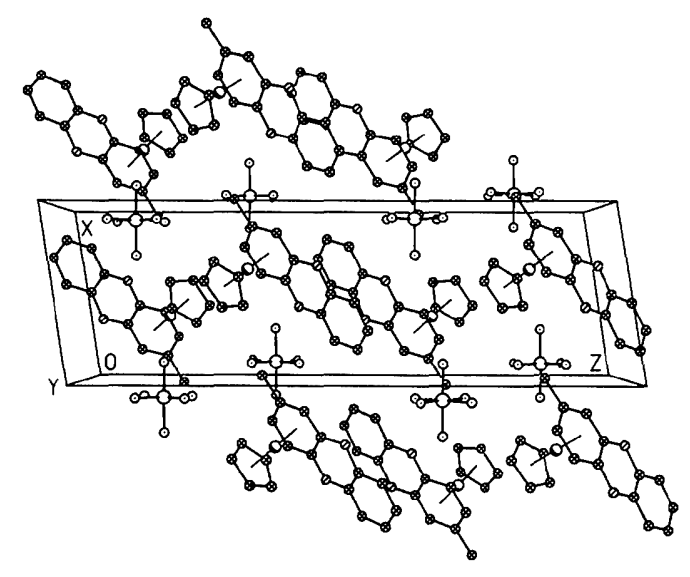

Fig. 2. The packing diagram for (1).

uncoordinated rings which has al so been observed in similar compounds. The distances between the 0 atoms and the $C$ atoms of the coordinated ring are shorter than those of the uncoordinated one; 05$\mathrm{C} 4 \mathrm{a}$ is $1.346(4)$ whereas $05-\mathrm{C} 5 \mathrm{a}$ is 1.386 (4) A; 010-C10a is 1.369 (4) compared to 1.401 (4) A for 010-c9a. This may be due to the electron-withdrawing power of the FeCp moiety.

The distance between $\mathrm{Fe}$ and the $\mathrm{Cp}$ ring plane, 1.659 (4) $A$, is longer than the distance between $F e$ and the coordinated arene ring planes, 1.548 (4) A. These distances are well within the range of similar compounds (Lynch et a!., 1986; Simonsen et a!., 1985). The dihedral angle between the $C p$ ring plane and the coordinated arene is $2 \cdot 1$ (It.

The $\mathrm{PF}_{6}$ group is reasonably well behaved with the $\mathrm{P}-\mathrm{F}$ bonding distance ranging between $\mathrm{I} .543$ (3) and 1.592 (3) A. No F-P-F angle deviates from the octahedral geometry by more than 1.50 .

The packing diagram for $(I)$ is given in Fig. 2.

SHS acknowledges the support of the Robert $A$. Welch Foundation (Grant F-017), and RGS the financial support of the Natural Sciences and Engineering Research Council of Canada.

\section{References}

ABBOUD, K. A., LYNCH, V. M., SIMONSEN, S. H., PIORKO, A. \& SUTHERLAND, R. G. (1990). Acta Cryst. C46, 1018-1022.

BOER, F. B. \& NORTH, P.P. (1972). Acta Cryst. B28, 1613-1618.

BOER, F. B., VAN REM OORTERE, F. P., NORTH, P.P. \& NEUMAN, M. A. (1972). Acta Cryst. B28, 1023-1028.

CALDWELL, S. R., MARTIN, G. E., SIM ONSEN, S. H., INNERS, R. R. \& WILL COTT, M. R. II (1981). J . Heterocycl. Chern. 18,479-484. CANTRELL, J. S., WEBB, N.C. \& M ABIS. A. J . (1969). Acta Cryst. B25, 150-155.

CORDES, A. W. (1983). Personal communication.

CROMER, D. T. \& LIBERMAN, D. (1970). J. Chern. Phys. 53, 1891-1898.

CROMER, D. T. \& MANN, J. B. (1968). Acta Cryst. A24, 321-324.

GADOL, S. M. \& DAVIS, R. E. (1982). Organornetallics, I, 1607-1613. 
HOSSAIN, M.B., DWIGGINS, C. A., VANDER HELM, D., GUPTA, P. K. S., TURLEY, 1. C. \& MARTIN, G. E. (1982). Acta Cryst. B 38, 881-888.

KIMURA, M. \& SIM ONSEN, S. H. (1981). Unpublished results.

LARSON, S. B., SIMONSEN, S. H., LA,M, W. W., MARTIN, G. E., LINDSAY, C. M. \& SMITH, K. (1985). Acta Cryst. C41, 1784-1786

LARSON, S. B., SIMONSEN, S. H., MARTIN, G. E. \& SMITH, K. (1985). Acta Cryst. C41, 1781-1783.

LARSON, S. B., SIMONSEN, S. H., MARTIN, G. E. SMITH, K. \& PmG-TORRES, S. (1984). Acta Cryst. C40, 103-106.

LYNCH, V. M., SIM ONSEN, S. H., M ARTIN, G.E.,PmG-TORRES, S. \& SMITH, K. (1984). Acta Cryst. C 40, 1483-1486.

LYNCH, V. M., THOMAS, S. N., SIMONSEN, S. H., PI6RKO, A. \& SUTHERLAND, R. G. (1986). Acta Cryst. C42, 1144--1148.

MARTIN, G. E., KORP, J.D., TURLEY, J.C. \& BERNAL, I. (1978). J . Heterocycl. Chern. 15, 721-729.
PuiG-TORRES, S., MARTIN, G. E., LARSON, S. B. \& SIM ONSEN, S. H. (1984). J. Heterocycl. Chern. 21, 995-1000.

RILEY, P. E. \& DAVIS, R. E. (1976). Acta Cryst. B 32, 381-386.

SHELDRICK, G. M. (1976). SHELX76. Program for crystal structure determination. Univ. of Cambridge, England.

SIM ONSEN, S. H., LYNCH, V. M., SUTHERLAND, R. G. \& PIORKO, A. (1984). Am. Crystal/ogr. Assoc. Ser. 2, 12, 27.

SIMONSEN, S. H., LYNCH, V. M., SUTHERLAND, R. G. \& PIORKO, A. (1985). J . Organomet. Chern. 290, 387-400.

SINGH, P. \& M CK IN NEY , J.D. (1978). Acta Cryst. B 34, 2956-2957. STEWART, R. F., DAVIDSON, E. R. \& SIMPSON, W. T. (1965). J . Chern. Phys. 42, 3175-3187.

SUTHERLAND, R. G., PI6RKO, A., LEE, C. C., SIMONSEN, S. H. \& LY N CH, V. M. (1988). J . Heterocycl. Chern. 25, 1911-1916.

WEAKLEY, R. (1982). Cryst. Struct. Commun. 11, 681-684.

WOMACK, C. H., TURLEY, J. C., MARTIN, G. E., KIMURA, M. \& SIM ONSEN, S. H. (1981). J. Heterocyc/. Chern. 18, 1173-1178. 